\title{
Helminth metacommunity structure of wild rodents in a preserved area of the Atlantic Forest, Southeast Brazil
}

\author{
Estrutura da metacomunidade de helmintos de roedores silvestres em uma área preservada da \\ Floresta Atlântica, sudeste do Brasil
}

\begin{abstract}
Thiago dos Santos Cardoso ${ }^{1,2}$; Caryne Aparecida de Carvalho Braga ${ }^{3}$; Carla Elizabeth Macabu ${ }^{1}$; Raquel de Oliveira Simóes ${ }^{1}$; Sócrates Fraga da Costa-Neto ${ }^{4,5}$; Arnaldo Maldonado Júnior ${ }^{1}$; Rosana Gentile ${ }^{1 *}$; José Luis Luque ${ }^{6}$

${ }^{1}$ Laboratório de Biologia e Parasitologia de Mamíferos Silvestres Reservatórios, Instituto Oswaldo Cruz, Fundação Oswaldo Cruz FIOCRUZ, Rio de Janeiro, RJ, Brasil

${ }^{2}$ Programa de Pós-graduação em Ciências Veterinárias, Departamento de Parasitologia Animal, Universidade Federal Rural do Rio de Janeiro - UFRRJ, Seropédica, RJ, Brasil

${ }^{3}$ Núcleo de Pesquisa Ecológica de Macaé, Universidade Federal do Rio de Janeiro - UFRJ, Macaé, RJ, Brasil

${ }^{4}$ Fiocruz Mata Atlântica, Fundação Oswaldo Cruz - FIOCRUZ, Rio de Janeiro, RJ, Brasil

${ }^{5}$ Programa de Pós-graduação em Biodiversidade e Saúde, Instituto Oswaldo Cruz - FIOCRUZ, Rio de Janeiro, RJ, Brasil

${ }^{6}$ Departamento de Parasitologia Animal, Universidade Federal Rural do Rio de Janeiro - UFRRJ, Seropédica, RJ, Brasil
\end{abstract}

Received June 8, 2018

Accepted August 10, 2018

\begin{abstract}
The helminth fauna and metacommunity structure of eight sympatric sigmodontine rodents were investigated at the Serra dos Órgãos National Park, an Atlantic Forest reserve located in the State of Rio de Janeiro, southeast Brazil. Rodents of the species Abrawayaomys ruschii, Akodon montensis, Blarinomys breviceps, Delomys dorsalis, Oligoryzomys flavescens, Oligoryzomys nigripes, Oxymycterus quaestor and Thaptomys nigrita were found infected with helminths. Akodon montensis presented the highest total helminth species richness, with six different species of helminths. The nematode Stilestrongylus lanfrediae was the most abundant and prevalent helminth species observed. The host-parasite network analysis showed little interactions among host species. Akodon montensis seems to act as a keystone-species in the rodent community. This species shared the nematodes Stilestrongylus aculeata with $A$. ruschii and Protospirura numidica criceticola with $T$. nigrita, and the cestode Rodentolepis akodontis with $D$. dorsalis. The congeners host species $O$. flavescens and $O$. nigripes shared the nematodes Guerrerostrongylus zetta and S. lanfrediae. The rodents B. breviceps and O. quaestor did not share any helminths with other hosts. The helminth metacommunity showed a random pattern on both infracommunity and component community levels, indicating different responses by each helminth species to the environmental gradient.
\end{abstract}

Keywords: Elements of metacommunity structure, network analysis, parasitism, small mammals.

\section{Resumo}

Foram investigadas a helmintofauna e suas estruturas da metacomunidade em oito roedores sigmodontíneos simpátricos ao longo do Parque Nacional da Serra dos Órgãos, uma reserva de Mata Atlântica no estado do Rio de Janeiro, Brasil. Roedores das espécies Abrawayaomys ruschii, Akodon montensis, Blarinomys breviceps, Delomys dorsalis, Oligoryzomys flavescens, Oligoryzomys nigripes, Oxymycterus quaestor e Thaptomys nigrita foram infectados por helmintos. Akodon montensis apresentou a maior riqueza total de espécies de helmintos, com seis espécies. O nematoide Stilestrongylus lanfrediae foi a espécie de helminto com maior abundância e prevalência. A análise de rede parasito-hospedeiro mostrou poucas interaçóes entre as espécies hospedeiras e $A$. montensis atuou como uma espécie-chave na comunidade de roedores. Esta espécie compartilhou os nematoides Stilestrongylus aculeata $\operatorname{com}$ A. ruschii e Protospirura numidica criceticola com T. nigrita, e o cestoide Rodentolepis akodontis com $D$. dorsalis. As espécies congêneres $O$. flavescens e $O$. nigripes compartilharam os nematoides Guerrerostrongylus zetta e $S$. lanfrediae. Os roedores B. breviceps e O. quaestor não compartilharam helmintos com outros hospedeiros. A metacomunidade de helmintos mostrou um padrão aleatório em ambos os níveis, comunidade componente e infracomunidade, indicando diferentes respostas de cada espécie de helminto ao gradiente ambiental.

Palavras-chave: Elementos de estrutura de metacomunidade, análise de rede, parasitismo, pequenos mamíferos.

*Corresponding author: Rosana Gentile. Laboratório de Biologia e

Parasitologia de Mamíferos Silvestres Reservatórios, Instituto Oswaldo Cruz,

Fundação Oswaldo Cruz - FIOCRUZ, Avenida Brasil, 4365, CEP 21040-900,

Rio de Janeiro, RJ, Brasil. e-mail: rgentile@ioc.fiocruz.br 


\section{Introduction}

Parasites have important ecological roles in ecosystems because they affect the fitness of their hosts, promote changes in their physiology and population dynamics, regulate host populations, mediate competition and predation, and influence diversity through a cascade effect (POULIN, 2007). The occurrence and distribution of parasites in host populations depend on several factors that include host and parasite attributes, such as phylogenetic relationships, host behavior, susceptibility to parasites (BROUAT et al., 2007; WOLINSKA \& KING, 2009), as well as characteristics of the environment such as seasonality and habitat (WOLINSKA \& KING, 2009; SIMÓES et al., 2010; CASTRO et al., 2017).

Due to their biological and ecological features, rodents and helminths are a good model for ecological studies of host-parasite interactions in different ecosystems (MALDONADO JR. et al., 2006; CARDOSO et al., 2016; SIMÓES et al., 2016). Rodents are the most diversified group of mammals (PATTON et al., 2015), may harbor a number of parasites and are reservoirs of several zoonoses (HAN et al., 2015). Helminths may show high biomass indices within a biological community (POULIN, 2007), and can be used as indicators of environmental changes (VIDALMARTÍNEZ \& WUNDERLICH, 2017). In addition, many helminth species have complex life cycles in which rodents act as intermediate and / or definitive hosts (CHAISIRI et al., 2017).

Therefore, information on the occurrence, distribution and community structure of parasites are fundamental to understand the ecosystem dynamics, the host-parasite interactions, and are essential for the knowledge of biodiversity. In addition, studies of community ecology and network analysis helps to describe and evaluate the patterns of distribution, abundance, and interactions between animal species. These patterns occur at different spatial scales with local communities interacting and affecting each other on a regional scale (PRESLEY et al., 2010).

The metacommunity approach has been recently used in community ecology to understand how species are distributed in communities and how these species respond to ecological changes at different spatial scales (LEIBOLD \& MIKKELSON, 2002; DÜMMER et al. 2016; BRAGA et al., 2017). A metacommunity is a set of local communities that potentially interact by species dispersal (LEIBOLD \& MIKKELSON, 2002). The application of the metacommunity theory in parasite ecology helps to understand host-parasite interactions both on the infracommunity scale (host individuals) and on the component communities (populations of a host species) (DALLAS \& PRESLEY, 2014).

Helminth communities of wild animals are still poorly understood, given the diversity of species that this group shows and their distinct patterns of host specificity and susceptibility (HUGOT et al., 2001; POULIN, 2007). Most of the studies about helminths of rodents in Brazil report helminth faunas or occurrences of specific parasites (MALDONADO JR. et al., 2010; PINTO et al., 2011; ARAUJO et al., 2014; WERK et al., 2016). Few studies reported the helminth community structure of wild small mammals (MALDONADO JR. et al., 2006; PÜTTKER et al., 2008; SIMÓES et al., 2010, 2011). Moreover, studies using the metacommunity approach for this interaction are scant (COSTA, 2017; COSTA-NETO et al., 2018).

The present study is part of a research project on biodiversity and aimed at investigating the fauna of several taxa in areas of the Atlantic Forest, including taxonomic, evolutionary, ecological and parasitological aspects. Herein, we describe the helminth fauna of Sigmodontine rodents in Serra dos Órgãos National Park (PARNASO), State of Rio de Janeiro, southeast Brazil. Our study also aimed at understanding the pattern of the structure of the helminth communities in rodent hosts. Considering the environmental gradient at the infracommunity scale as host individuals and at the component community scale as host species, we tested the following hypotheses: 1) Host species with greater ecological and biological similarity tend to share parasite species, due to the evolutionary processes involving adaptation between parasites and hosts; 2) The helminth metacommunity is non-randomly structured (coherent structure) in both scales, as we expect more similar species of parasites within each host species and also a certain level of similarity in closely related species of hosts.

\section{Materials and Methods}

\section{Study area}

Rodent sampling was carried out at the PARNASO, Municipality of Petrópolis, which is a preserved forest with an area of 20,024 ha. This park is internationally recognized as a Biosphere Reserve and is one of the most important Atlantic Forest remnants in Brazil. The municipality of Petrópolis covers $43 \%$ of the area of the PARNASO which also comprises the municipalites of Teresópolis, Magé, and Guapimirim (ICMBIO, 2014). The study area presents continuous, dense, ombrophilous vegetation of Mountain Atlantic Forest. The climate of this region is highland mesothermic (Cwb), according to Köppen's classification, with mild temperatures, rainy summers, and a dry season between June and August (AYOADE, 1986). Trappings were conducted in three localities of the park: Bonfim (22027’36.2”S 4305'37"W; $1074 \mathrm{~m}$ height), Barragem do Caxambú (22³0'20"S 4306'47.5”W; $1117 \mathrm{~m}$ height) and Uricanal (22。29'20.5”S 4307’27.8”W; $1056 \mathrm{~m}$ height) in late spring 2014 (rainy season) and winter 2015 (dry season).

\section{Sampling and examination of rodents}

Samplings consisted of 10 linear transects, each set for 10 consecutive days. Six of these transects had 15 points with two live traps on the ground, one Tomahawk trap $(40.64 \mathrm{~cm} \times 12.70 \mathrm{~cm} \times 12.70 \mathrm{~cm})$ and one Sherman trap $(7.62 \mathrm{~cm} \times 9.53 \mathrm{~cm} \times 30.48 \mathrm{~cm})$, and six additional traps in the understorey, three of each type intercalated. These traps were baited with a mixture of peanut butter, banana, oats and bacon. Four transects had 20 points, with pitfall traps spaced $10 \mathrm{~m}$ apart. Rodents were euthanized and necropsied, and their bionomic data recorded (age, gender, reproductive activity, body mass and external measurements). Rodents were identified based on their external features, cranial morphology and cytogenetics analysis (diploid number). 
Animals were captured under authorization of the Brazilian Government's Chico Mendes Institute for Biodiversity and Conservation (ICMBIO, license number 45839- 1). All procedures followed the guidelines for capture, handling and care of animals of the Ethical Committee on Animal Use of the Oswaldo Cruz Foundation (CEUA license number LW - 39/14). Biosafety techniques and personal safety equipment were used during all procedures involving animal handling and biological sampling.

Nematodes, trematodes and cestodes were recovered from the lungs, bile ducts, stomach, small intestine and cecum, and thoracic and abdominal cavities and washed in saline solution $(\mathrm{NaCl} 0.85 \%)$. Some of the specimens were fixed in AFA (acetic acid $2 \%$, formaldehyde $3 \%$ and ethanol $95 \%$ ) and some were stored in $70 \%$ ethanol for further molecular analysis. Nematodes were cleared in lactophenol. Trematodes and cestodes were stained with chlorhydric carmine. Taxonomic identification of these parasites was carried out based on Travassos (1937), Yamaguti (1961), Khalil et al. (1994), Vicente et al. (1997) and Bray et al. (2008). Voucher specimens of the rodents were deposited at the National Museum of Rio de Janeiro, Brazil. Voucher specimens of helminths were deposited at the Helminthological Collection of the Oswaldo Cruz Institute, in Rio de Janeiro, Brazil (CHIOC numbers 38556 , $38557,38558,38559,38560,38561,38562$ and 38563).

\section{Data analysis}

Parasitological parameters were calculated for each species of helminth according to Bush et al. (1997) for infracommunities (communities within an individual host) and component communities (communities including the entire host population). Mean abundance was considered as the total number of helminths recovered divided by the number of rodents examined. Prevalence of each species was calculated as the proportion of the infected rodents for a given helminth species in relation to the total number of analysed rodents. Confidence intervals of prevalence were calculated based on the standard deviation considering $\alpha=95 \%$. Importance indexes of species of helminths (each component community) were calculated according to Thul et al. (1985), considering the number of infected hosts and the total abundance of each helminth species. Each species of helminth was classified in the community as dominant species $(I \geq 1.0)$ representing the most abundant and prevalent species in the community, co-dominant $(0.01 \leq \mathrm{I}<1.0)$, which contributed significantly to the community but in a lesser degree than the dominant species, and subordinate $(0<\mathrm{I}<0.01)$, which occurred infrequently.

The analysis of ecological networks was carried out to verify the interactions between hosts and helminth species. The analysis was based on a matrix of presence / absence of each helminth species in each host. A bipartite network was built between rodent species and helminth species. This type of network indicates the connectance between two different sets - in this case the connectance between hosts and parasites (POULIN, 2010).

The metacommunity structure of the helminths found in the sigmodontine rodents was investigated at the level of infracommunity, considering each individual host as a site, and at the component community level as well, considering each host species as a site.
According to this analysis, sites with no species occurrence must not be included in the species incidence matrix (LEIBOLD \& MIKKELSON, 2002). The three elements of metacommunity structure (EMS) (coherence, turnover and boundary clumping), were evaluated according to the method described by Leibold and Mikkelson (2002) and Presley et al. (2010). The coherence element tests whether species respond to the same environmental gradient, quantifying the number of embedded absences (absences localized between two species occurrences) on a species incidence matrix ordered by Reciprocal Averaging. When the coherence element is significant, the turnover and boundary clumping are also assessed. The turnover element determines whether the processes that structure the diversity lead to substitution or loss of species along the gradient, and is calculated by the number of species replacements in the incidence matrix. Boundary clumping is the third element and quantifies the overlap of species distribution limits in the environmental gradient, which can be clumped (when the index value is greater than 1), hyperdispersed (when the index is less than 1) or random (when boundary clumping is not statistically significant) (PRESLEY et al., 2010; BRAGA et al., 2017).

The network analysis was performed in RStudio software version 1.0.136 using the bipartite package. The host-parasite interaction matrix was visualized using 'plotweb' function (DORMANN et al., 2008). The analysis of Metacommunity structure was performed in Matlab R2018a software (MathWorks) using the EMS Script (HIGGINS, 2008). The significance level was $5 \%$ in all the analyses.

\section{Results}

Eight species of sigmodontine rodents were infected with helminths: Abrawayaomys ruschii Cunha \& Cruz, $1979(\mathrm{n}=2)$, Akodon montensis Thomas, 1913 ( $\mathrm{n}=62$ ), Blarinomys breviceps (Winge, 1887) ( $\mathrm{n}=4)$, Delomys dorsalis (Hensel, 1872) $(\mathrm{n}=8)$, Oligoryzomys flavescens (Waterhouse, 1837) $(\mathrm{n}=2)$, Oligoryzomys nigripes (Olfers, 1818) ( $\mathrm{n}=43)$, Oxymycterus quaestor Thomas, $1903(\mathrm{n}=4)$ and Thaptomys nigrita (Lichtenstein, 1829) $(\mathrm{n}=4)$ (Rodentia: Cricetidae) (in parenthesis are the number of animals analysed). The host species that presented the highest total helminth species richness was $A$. montensis. However, $O$. flavescens and T. nigrita presented the highest mean species richness (Table 1).

Akodon montensis was infected with six helminth species: the nematodes Protospirura numidica criceticola (Quentin, Karimi \& Rodrigues De Almeida, 1968), Stilestrongylus aculeata (Travassos, 1918), Stilestrongylus eta (Travassos, 1937) and Trichofreitasia lenti Sutton \& Durette-Desset, 1991, the trematode Canaania obesa (Travassos, 1944), and the cestode Rodentolepis akodontis (Rêgo, 1967). The most prevalent and abundant species in this rodent was $S$. aculeata (Tables 1 and 2). Delomys dorsalis was parasitized by two helminth species only: the nematode Alippistrongylus sp. and $R$. akodontis, both showing mid-term prevalence and low abundance (Tables 1 and 2). Three nematode species occurred in T. nigrita: $P$. $n$ criceticola, Pterygodermatites $\mathrm{sp}$. and Stilestrongylus sp. (Tables 1 and 2). Oligoryzomys nigripes and O. flavescens had two helminth species with high prevalence: the nematodes Guerrerostrongylus zetta (Travassos, 1937) Sutton and 
Table 1. Prevalence (\%) with 95\% confidence limits and helminth species mean richness of sigmodontine rodents from Serra dos Órgãos National Park, Petrópolis, State of Rio de Janeiro, southeast Brazil. Total number of hosts captured and number of infected hosts are in parentheses.

\begin{tabular}{|c|c|c|c|c|c|c|c|c|}
\hline $\begin{array}{l}\text { Helminth species } \backslash \\
\text { Rodent species }\end{array}$ & A. ruschii & A. montensis & B. breviceps & D. dorsalis & O. flavescens & O. nigripes & O. quaestor & T. nigrita \\
\hline & 2(1) & 62(19) & $4(1)$ & 8(2) & $2(2)$ & $43(23)$ & $4(1)$ & $4(2)$ \\
\hline Mean richness & 0.5 & 0.45 & 0.25 & 0.25 & 1.5 & 0.69 & 0.25 & 1 \\
\hline Alippistrongylus sp. & - & - & - & $12.5(10.1-14.8)$ & - & - & - & - \\
\hline G. zetta & - & - & - & - & $50.0(46.8-53.1)$ & $20.9(17.3-24.5)$ & - & - \\
\hline Litomosoides sp. & - & - & - & - & - & - & $25(0-87.7)$ & - \\
\hline P. n. criceticola & - & $4.8(1-13.5)$ & - & - & - & - & - & $50(39.6-60.3)$ \\
\hline Pterygodermatites sp. & - & - & - & - & - & - & - & $25(21.8-28.1)$ \\
\hline S. aculeata & $50(40.5-59.4)$ & $17.7(9.2-29.5)$ & - & - & - & - & - & - \\
\hline S. eta & - & $6.5(1.8-15.7)$ & - & - & - & - & - & - \\
\hline S. lanfrediae & - & - & - & - & $100(71.0-128.2)$ & $48.8(15.1-82.5)$ & - & - \\
\hline Stilestrongylus sp. & - & - & - & - & - & - & - & $25(23.4-26.5)$ \\
\hline T. lenti & - & $4.8(1-13.5)$ & - & - & - & - & - & - \\
\hline R. akodontis & - & $6.5(1.8-15.7)$ & - & $12.5(11.7-13.2)$ & - & - & - & - \\
\hline Cestoda & - & - & $25(23.4-26.5)$ & - & - & - & - & - \\
\hline C. obesa & - & $4.8(1-1.35)$ & - & - & - & - & - & - \\
\hline
\end{tabular}

Table 2. Mean abundance followed by standard error of helminth species of sigmodontine rodents from Serra dos Órgãos National Park, Petrópolis, State of Rio de Janeiro, southeast Brazil. Total number of hosts captured and infected are in parentheses.

\begin{tabular}{|c|c|c|c|c|c|c|c|c|}
\hline \multirow{2}{*}{$\begin{array}{l}\text { Helminth species / } \\
\text { Rodent species }\end{array}$} & A. ruschii & $\frac{\text { A. montensis }}{62(10)}$ & B. breviceps & D. dorsalis & $\frac{\text { O. flavescens }}{2(2)}$ & O. nigripes & O. quaestor & T. nigrita \\
\hline & $2(1)$ & $62(19)$ & $4(1)$ & $8(2)$ & $2(2)$ & $43(23)$ & $4(1)$ & $4(2)$ \\
\hline Alippistrongylus sp. & - & - & - & $0.37 \pm 1.06$ & - & - & - & - \\
\hline G. zetta & - & - & - & - & $0.50 \pm 0.57$ & $1.16 \pm 3.77$ & - & - \\
\hline Litomosoides sp. & - & - & - & - & - & - & $10.00 \pm 20.00$ & - \\
\hline P. n. criceticola & - & $0.06 \pm 0.30$ & - & - & - & - & - & $2.25 \pm 3.30$ \\
\hline Pterygodermatites sp. & - & - & - & - & - & - & - & $0.50 \pm 1.00$ \\
\hline S. aculeata & $1.50 \pm 2.12$ & $8.27 \pm 33.97$ & - & - & - & - & - & - \\
\hline S. eta & - & $2.19 \pm 14.47$ & - & - & - & - & - & - \\
\hline S. lanfrediae & - & - & - & - & $13.50 \pm 6.36$ & $19.41 \pm 35.21$ & - & - \\
\hline Stilestrongylus sp. & - & - & - & - & - & - & - & $0.25 \pm 0.50$ \\
\hline T. lenti & - & $0.04 \pm 0.21$ & - & - & - & - & - & - \\
\hline R. akodontis & - & $0.11 \pm 0.48$ & - & $0.12 \pm 0.35$ & - & - & - & - \\
\hline Cestoda & - & - & $0.25 \pm 0.50$ & - & - & - & - & - \\
\hline C. obesa & - & $0.25 \pm 1.41$ & - & - & - & - & - & - \\
\hline
\end{tabular}

Durette-Desset, 1991 and Stilestrongylus lanfrediae Souza, Digiani, Simóes, Luque, Rodrigues-Silva \& Maldonado Jr., 2009, the later with larger abundance (Tables 1 and 2).

Abrawayamys ruschii, $O$. quaestor and B. breviceps had the lowest helminth richness, with only one species in each component community: S. aculeata, Litomosoides sp. and a cestode, respectively, all of them with only one infected specimen (Tables 1 and 2).

Some helminths could not be identified to the species level. The specimen of the genus Pterygodermatites was not identified to specific level because only one female specimen was recovered. For the genus Stilestrongylus and Alippistrongylus, only one male specimen was recovered from each host species. The only specimen of cestode recovered from $B$. breviceps was not well preserved.

\section{Helminth community structure}

Except for the component communities that presented only one species, the ones for $A$. ruschii, B. breviceps and $O$. quaestor, no helminth species was considered dominant in any of the other component communities examined (Table 3). In A. montensis, S. eta and $S$. aculeata were co-dominant species and the other species were subordinate. In the other hosts, all helminth species were considered co-dominants (Table 3).

The host-parasite network analysis showed little interactions among rodent species regarding helminth metacommunity (Figure 1). Akodon montensis shared three helminth species with other hosts: $S$. aculeata with $A$. ruschii, $R$. akodontis with $D$. dorsalis and $P$. n. criceticola with T. nigrita (Figure 1). Oligoryzomys nigripes 
and $O$. flavescens shared the two helminth species found: G. zetta and S. lanfrediae (Figure 1). Blarinomys breviceps and O. quaestor did not share any helminths with other hosts (Figure 1).

The helminth metacommunity structure was random on both levels (with no significant coherence), considering the infracommunities

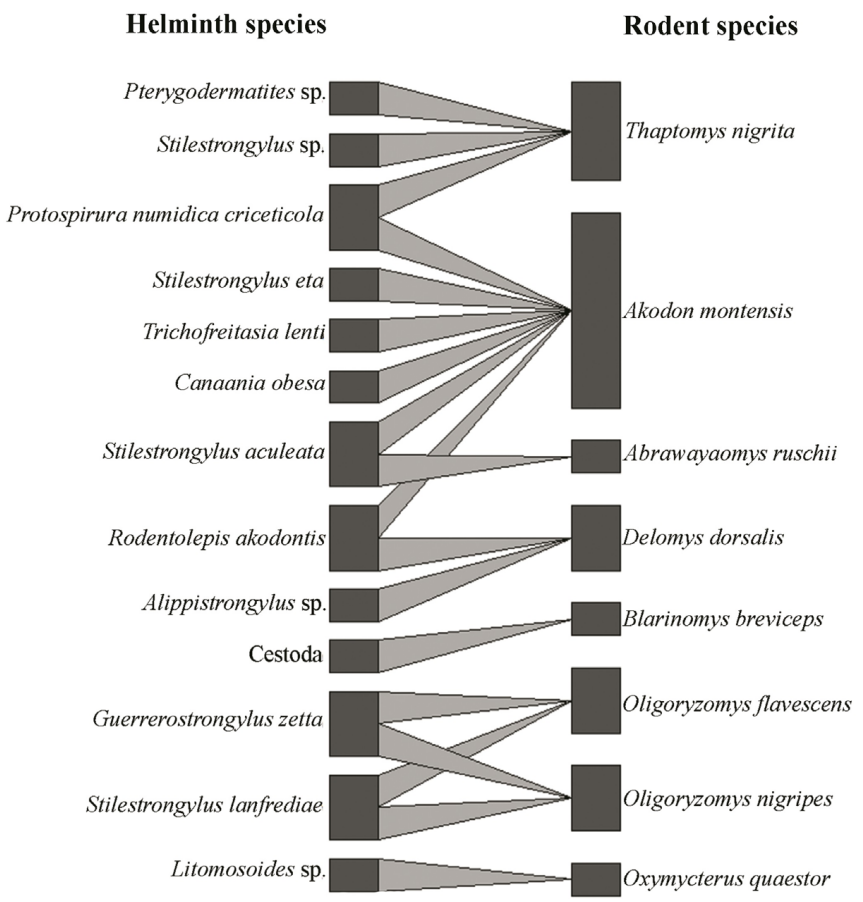

Figure 1. The bipartite network analysis illustrates the rodent-helminth association in Serra dos Órgãos National Park, Petrópolis, State of Rio de Janeiro, southeast Brazil.
(Embedded absences $=71, \mathrm{p}=0.27$, mean $=155.75$, standard deviation $=77.23)$ or component communitites $($ Embedded absences $=12, \mathrm{p}=0.71$, mean $=9.83$, standard deviation $=5.97$ ), according to the EMS analysis. This pattern is characterized by independent responses of each species to the environmental gradient, i.e., helminth species distribution are independent of each other. Figure 2 shows the occurrence of each helminth species in each rodent specimen, which represent the infracommunities (A), and in each rodent species, which represent the component communities (B), indicating that helminth species are randomly distributed along both gradients.

\section{Discussion}

\section{Rodent helminth fauna}

The highest total helminth species richness in A. montensis (six) in comparison with other rodents corroborates the results from other surveys which also found greater richness in this host (PÜTTKER et al., 2008; PANISSE et al., 2017). However, the total helminth species richness found for this rodent was lower than those reported in other studies; Püttker et al. (2008) observed seven morphotypes in a study in the State of São Paulo, Brazil; Panisse et al. (2017) reported eight helminth species for this rodent in Misiones Province, Argentina. In a previous study carried out in a different locality in PARNASO (Teresópolis) and in forest fragments on its surroundings, Simóes et al. (2011) reported twelve helminth species in $A$. montensis, considering 13 localities. Regarding the mean helminth species richness, although $A$. montensis was the most abundant species in the present study, other host species (O. flavescens and T. nigrita) also showed higher mean

Table 3. Importance indices for the helminths that occur in sigmodontine rodents from Serra dos Órgãos National Park, Petrópolis, State of Rio de Janeiro, southeast Brazil.

\begin{tabular}{|c|c|c|}
\hline Host species and helminths & Importance Indices & Classification \\
\hline \multicolumn{3}{|l|}{ Akodon montensis } \\
\hline Canaania obesa & 0.007 & Subordinate \\
\hline Protospirura numidica criceticola & 0.001 & Subordinate \\
\hline Rodentolepis akodontis & 0.004 & Subordinate \\
\hline Stilestrongylus aculeata & 0.897 & Co-dominant \\
\hline Stilestrongylus eta & 0.086 & Co-dominant \\
\hline Trichofreitasia lenti & 0.001 & Subordinate \\
\hline \multicolumn{3}{|l|}{ Delomys dorsalis } \\
\hline Alippistrongylus sp. & 0.750 & Co-dominant \\
\hline Rodentolepis akodontis & 0.250 & Co-dominant \\
\hline \multicolumn{3}{|l|}{ Oligoryzomys nigripes } \\
\hline Guerrerostrongylus zetta & 0.025 & Co-dominant \\
\hline Stilestrongylus lanfrediae & 0.974 & Co-dominant \\
\hline \multicolumn{3}{|l|}{ Oligoryzomys flavescens } \\
\hline Guerrerostrongylus zetta & 0.018 & Co-dominant \\
\hline Stilestrongylus lanfrediae & 0.981 & Co-dominant \\
\hline \multicolumn{3}{|l|}{ Thaptomys nigrita } \\
\hline Stilestrongylus sp. & 0.047 & Co-dominant \\
\hline Protospirura numidica criceticola & 0.857 & Co-dominant \\
\hline Pterygodermatites sp. & 0.095 & Co-dominant \\
\hline
\end{tabular}


A

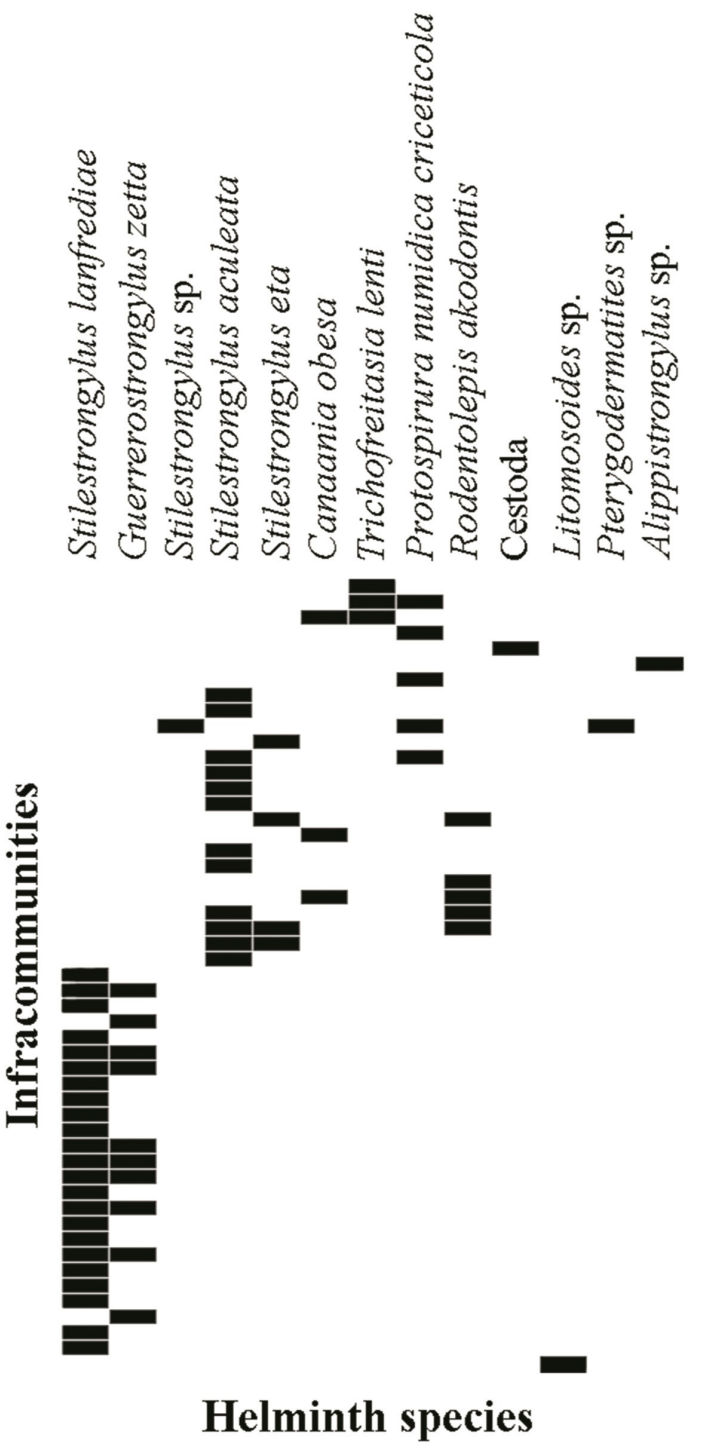

B
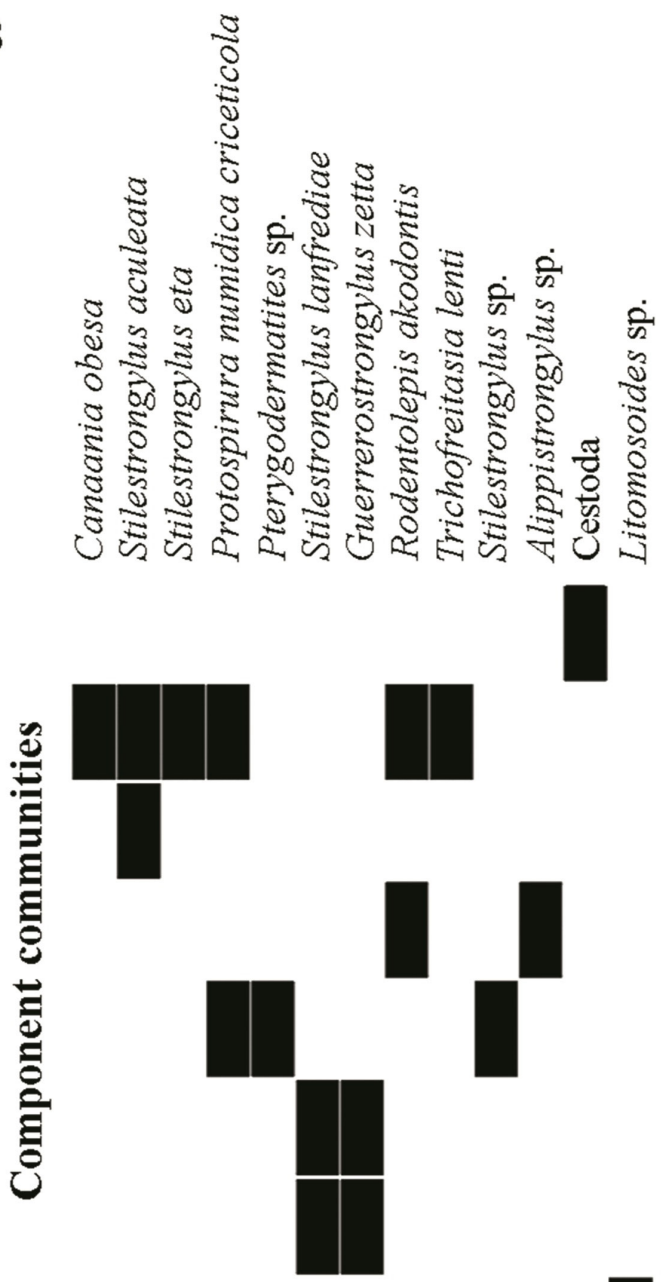

Helminth species

Figure 2. Ordinated matrices for the helminths metacommunities in Serra dos Órgãos National Park, Petrópolis, State of Rio de Janeiro, southeast Brazil: A) infracommunities and B) component communities.

richness. These findings suggest a greater susceptibility of their infracommunities to infection and may reflect co-occurrence between their helminth species.

Considering the helminth fauna of $A$. montensis, all helminth species found in the present study were previously reported (MALDONADO Jr. et al., 2010; SIMÓES et al., 2011; PANISSE et al., 2017). Other genera and species already registered for this host include Angiostrongylus lenzii, S. Lanfrediae, Syphacia carlitosi, Litomosoides silvai, Trichuris sp., Echinostoma luisreyi in Brazil (SIMÓES et al., 2011; GRESSLER et al., 2017), Eucoleus sp., Platynosomoides sp., Tapironema coronatum and Trichuris navonae in Argentina (ROBLES, 2011; PANISSE et al., 2017).

For the rodent $O$. nigripes, the helminths $S$. lanfrediae and G. zetta were already registered in this host (SOUZA et al., 2009; SIMÓES et al., 2011; WERK et al., 2016; PANISSE et al., 2017). Other helminth species reported for $O$. nigripes are Avellaria sp., $S$. aculeata, S. eta, S. lanfrediae, Syphacia kinsellai, T. lenti, Litomosoides odilae, C. obesa, Cysticercus fasciolaris, Railletina sp. and R. akodontis at PARNASO (SIMÓES et al., 2011), Echinoparyphium scapteromae, Litomosoides bonaerensis, Litomosoides navonae, Stilestrongylus flavescens, Hassalstrongylus epsilon and T. coronatum in Argentina (NAVONE et al., 2009; PANISSE et al., 2017) and Trichuris travassosi in the State of Rio Grande do Sul, Brazil (GOMES et al., 1992).

Similarly, O. flavescens was infected only by S. lanfrediae and G. zetta. This a novel finding for this host. Sutton \& Lunaschi (1990) reported the occurrence of Urotrema scabridum in O. flavescens (syn. Oryzomys flavescens) in Uruguay. Sutton \& Durette-Desset (1991) recorded T. lenti and Stilestrongylus oryzomisi in Argentina and Guerrerostrongylus uruguayensis and S. flavescens in Uruguay in this host species. Navone et al. (2009) reported in this rodent the occurrence of E. scapteromae, L. bonaerensis, P. n. criceticola, S. flavescens, Syphacia sp. and Stilestrongylus sp. in Argentina.

Litomosoides sp. was the only helminth to infect the semifossorial rodent $O$. quaestor. Litomosoides legerae was recorded in $O$. quaestor 
in Teresópolis, Brazil (BAIN et al., 1980), Litomosoides oxymycteri was observed in Oxymycterus rufus (NOTARNICOLA et al., 2000; NAVONE et al., 2009) and Litomosoides anguyai in Oxymycterus misionalis (NOTARNICOLA et al., 2002), both in Argentina. Litomosoides nasuti was recorded in Oxymycterus nasutus in Uruguay (NOTARNICOLA \& NAVONE, 2009). In addition to these helminth species, Navone et al. (2009) also observed E. scapteromae, Levinseniella (Monarrhenos) cruzi, Zoonorchis oxymycterae, Rodentolepis sp., Pseudocapillaria sp., Nematomystes rodentiphilus and Suttonema sp. in O. rufus in Argentina. Jiménez-Ruiz \& Gardner (2003) recorded three nematode species infecting Oxymycterus paramensis in Bolivia, Caroloxyuris boliviensis, $N$. rodentiphilus and $P$. numidica.

The helminth fauna of $T$. nigrita was previoulsy described by Panisse et al. (2017). These authors reported the occurrence of a new species of the genus Stilestrongylus in Argentina. In the present study, the only specimen of Stilestrongylus found in T. nigrita seems to be the same species that was found by Panisse et al. (2017) based on the morphological characteristic observed. However, the authors did not provide further information. The nematodes T. navonae and Syphacia alata were also reported in this rodent in Argentina (ROBLES, 2010; ROBLES \& NAVONE, 2014; PANISSE et al., 2017).

The helminth fauna of $D$. dorsalis is largely unknown. The study conducted by Digiani \& Kinsella (2014) described a new genus and species of helminth, Alippistrongylus bicaudatus, in this rodent. In the present study, specimens found in $D$. dorsalis presented the same diagnostic characteristics of the genus Alippistrongylus (DIGIANI \& KINSELLA, 2014).

In our survey, the other hosts captured, $A$. ruschii and $B$. breviceps, which had very low abundance, are considered rare in small mammal inventories when compared to other rodents such as $A$. montensis (PEREIRA et al., 2008; CERBONCINI et al., 2014; MACHADO et al., 2016). Thus, for these species, there are no records of helminth infection published in the literature. Therefore, the occurrence of $S$. aculeata in $A$. ruschii represent a new host for this helminth.

\section{Helminth community structure}

Among the four co-dominant helminth species with the highest values of importance, two belong to the genus Stilestrongylus, $S$. aculeata in $A$. montensis and S. lanfrediae in O. flavescens and $O$. nigripes. Species of the genus Stilestrongylus are common among rodents, as 21 species among 23 in this genus have been reported to infect rodents of the families Cricetidae, Muridae and Echimyidae (BOULLOSA et al., 2018). The co-dominance of the species $P$. $n$. criceticola and $R$. akodontis in their respective hosts, T. nigrita and $D$. dorsalis, and subordinate in $A$. montensis may be due to the lower helminth species richness in the former hosts. In fact, parasites may show greater abundances in infracommunities with few helminth species when compared to rich species infracommunities (POULIN, 1997, 2007). The latter, in turn, may present species saturation or negative interactions among the parasites such as competition, which might have reduced the parasite load of each species (POULIN, 1997; MORAND et al., 1999).
Ecological networks represent a useful tool to further our understanding of the various host-parasite interactions (POULIN, 2010; DALLAS et al., 2017). They may be used to identify potential routes of parasite transmission among hosts and keystone species in a community (POULIN, 2010; BELLAY et al., 2015; CHAISIRI et al., 2017), and also to investigate host-parasite specificity and the consequences of species losses (BELLAY et al., 2015). In the present study, the bipartite network analysis of the rodent-helminth interactions suggests that $A$. montensis acts as a keystone species in the rodent community sharing parasites with other species. Parasite sharing is more likely to occur among biologically, ecologically or phylogenetically related host species (DALLAS \& PRESLEY, 2014; BELLAY et al., 2015).

Akodon montensis, which belongs to the Akodontini tribe (LEITE et al., 2014), is a terrestrial and opportunistic species in relation to habitat occupation (MELO et al., 2013; CARDOSO et al., 2016), and insectivorous (PAGLIA et al., 2012). Thaptomys nigrita and $D$. dorsalis, which shared helminth species with $A$. montensis, also have terrestrial habits. The former also belongs to the Akodontini tribe (LEITE et al., 2014) and have an insectivorous / omnivorous diet (PAGLIA et al., 2012), while the latter is frugivorous / granivorous (PAGLIA et al., 2012), and although it is incertae sedis (VILELA et al., 2014), it is also a sigmodontine. These similar ecological characteristics allow these rodents to explore resources in the environment in a pattern similar to the one of $A$. montensis, which may have facilitated the infection by the same helminth species. Although A. ruschii has a semifossorial habit (PAGLIA et al., 2012), the only species, $S$. aculeata, found in this rodent, which was also present in $A$. montensis, presents a direct life cycle. Helminth eggs are found in the soil (URQUHART et al., 1998), which favours the infection of both host species. Oligoryzomys nigripes and $O$. flavescens, which shared helminths only among themselves, are both of the Oryzomyini tribe (VILELA et al., 2014) and the only scansorial species of the host community studied (PAGLIA et al., 2012).

Metacommunities formed by parasites may respond coherently to the environmental gradient if hosts present similar suitable conditions, within and among host species, for the establishment, development and reproduction of the parasite populations. The random patterns observed for the helminths infracommunities and component communities indicate that species distributions are associated with different gradients, which may be related to the occurrence of helminth species with different environmental requirements and habitat heterogeneity (DALLAS \& PRESLEY, 2014; PRESLEY et al., 2010). The low number of parasite species shared among hosts and the presence of helminth species with different life cycles (direct and indirect) support the random pattern found in this study. However, we should also take into account that when the hosts have few helminth species richness and the number of host examined (number of sites) is limited, as in our study, the random pattern is likely to occur.

The present report is a novel study on helminth metacommunity structure of sigmodontine rodents in Brazil. This is the first report of a bipartite network analysis for Brazilian rodents and their helminth fauna. The first hypothesis was valid as rodent species with the greatest ecological and biological similarity were those that shared more helminth species such as $A$. montensis with $T$. nigrita, 
$A$. ruschii and $D$. dorsalis, and $O$. nigripes with $O$. flavescens. The findings on the helminth metacommunity structure of the sigmodontine rodents for the locality analysed contradict in part our second hypothesis, as we observed a random structure with different species responses to the environmental gradient (hosts) in both scales. It is probable that the few number of helminth species shared among rodent species has resulted in the random pattern for the helminth metacommunity studied, because local differences in the species composition of helminths among hosts may provide different responses to the environmental gradient.

\section{Acknowledgements}

The authors would like to thank the staff and students of Laboratório de Biologia e Parasitologia de Mamíferos Silvestres Reservatórios at Fiocruz and Laboratório de Vertebrados at UFRJ for helping in the field work; to Dr. R. Cerqueira for the ICMBio licence, to Dr. M. Weksler for the rodents' identification; to Dr. J. Souza for helping in the helminths identification, to Dr. R. Cerqueira and Dr. P. C. Estrela for the coordination of the general project PPBio Rede BioM.A. This project was financially supported by Conselho Nacional de Desenvolvimento Científico e Tecnológico - CNPq - PPBio Rede BioM.A (457524/2012-0), Instituto Oswaldo Cruz (IOC - FIOCRUZ), Laboratório de Vertebrados (UFRJ) and Programa de Pós-Graduação em Ciências Veterinárias (UFRRJ) and Programa de Pós-Graduação em Biodiversidade e Saúde (IOC-FIOCRUZ). TSC, CACB and SFCN received grants from Coordenação de Aperfeiçoamento de Pessoal de Nível Superior (CAPES) - Brasil - Finance code 001, CEM and ROS received grants from Fundação Carlos Chagas Filho de Amparo à Pesquisa do Estado do Rio de Janeiro (FAPERJ).

\section{References}

Araujo EO, Mendes MM, Langone PQ, Müller G. The helminth parasites of Rattus rattus (Linnaeus, 1758) of urban, intermediate and rural environments in southern Brazil. Neotrop Helminthol 2014; 8(1): 19-22.

Ayoade JO. Introdução a climatologia para os Trópicos. São Paulo: Editora Difel; 1986.

Bain O, Petit G, Berteaux S. Description de deux nouvelles Filaires du genre Litomosoides et de leurs stades infestants. Ann Parasitol Hum Comp 1980; 55(2): 225-237. http://dx.doi.org/10.1051/parasite/1980552225. PMid:7458160.

Bellay S, Oliveira EF, Almeida-Neto M, Abdallah VD, Azevedo RK, Takemoto RM, et al. The patterns of organisation and structure of interactions in a fish-parasite network of a Neotropical river. Int J Parasitol 2015; 45(8): 549-557. http://dx.doi.org/10.1016/j.ijpara.2015.03.003. PMid:25900213.

Boullosa RG, Simóes RO, Andrade-Silva BE, Gentile R, Maldonado A. A new heligmonellid (Nematoda) species of the genus Stilestrongylus in Euryoryzomys russatus (Rodentia: Sigmodontinae) in the Atlantic Forest, southern Brazil.J Helminthol 2018; 2018: 1-4. http://dx.doi.org/10.1017/ S0022149X18000251. PMid:29644944.
Braga C, Oliveira JA, Cerqueira R. Metacomunidades: uma introdução aos termos e conceitos. Oecol Aust 2017; 21(2): 108-118. http://dx.doi. org/10.4257/oeco.2017.2102.02.

Bray RA, Gibson DI, Jones A. Keys to the Trematoda. Vol. 3. London: CAB International and Natural History Museum; 2008. http://dx.doi. org/10.1079/9780851995885.0000.

Brouat C, Kane M, Diouf M, Bâ K, Sall-Dramé R, Duplantier JM. Host ecology and variation in helminth community structure in Mastomys rodents from Senegal. Parasitology 2007; 134(3): 437-450. http://dx.doi. org/10.1017/S003118200600151X. PMid:17076921.

Bush AO, Lafferty KD, Lotz JM, Shostak AW. Parasitology meets ecology on its own terms: Margolis et al. revisited. J Parasitol 1997; 83(4): 575 583. http://dx.doi.org/10.2307/3284227. PMid:9267395.

Cardoso TS, Simóes RO, Luque JL, Maldonado A, Gentile R. The influence of habitat fragmentation on helminth communities in rodent populations from a Brazilian Mountain Atlantic Forest. J Helminthol 2016; 90(4): 460-468. http://dx.doi.org/10.1017/S0022149X15000589. PMid:26206199.

Castro RGBM, Costa SFC No, Maldonado A Jr, Gentile R. Ecological aspects of nematode parasites of Didelphis aurita (Didelphimorphia, Didelphidae) in urban-sylvatic habitats in Rio de Janeiro, Brazil. Oecol Aust 2017; 21(1): 54-61. http://dx.doi.org/10.4257/oeco.2017.2101.06.

Cerboncini RAS, Zanata TB, Cunha WL, Rorato AM, Calefi AS, Sbegen MR, et al. Distribution extension of Abrawayaomys ruschii Cunha and Cruz, 1979 (Rodentia: Cricetidae) with the first records in the state of Paraná, southern Brazil. Check List 2014; 10(3): 660-662. http://dx.doi. org/10.15560/10.3.660.

Chaisiri K, Chou M, Siew CC, Morand S, Ribas A. Gastrointestinal helminth fauna of rodents from Cambodia: emphasizing the community ecology of host-parasite associations. J Helminthol 2017; 91(6): 726-738. http://dx.doi.org/10.1017/S0022149X16000869. PMid:27905270.

Costa NA. Composiçâa e estrutura das comunidades de helmintos de Necromys lasiurus (Lund, 1840) (Rodentia, Sigmodontinae), no município de Uberlândia, Minas Gerais, Brasil [dissertação]. Rio de Janeiro: Fundação Oswaldo Cruz; 2017.

Costa-Neto SF, Cardoso TS, Boullosa RG, Maldonado A, Gentile R. Metacommunity structure of the helminths of the black-eared opossum Didelphis aurita in peri-urban, sylvatic and rural environments in southeastern Brazil. J Helminthol 2018; 1-12. http://dx.doi.org/10.1017/ S0022149X18000780. PMid:30220264.

Dallas T, Park AW, Drake JM. Predicting cryptic links in host-parasite networks. PLOS Comput Biol 2017; 13(5): e1005557. http://dx.doi. org/10.1371/journal.pcbi.1005557. PMid:28542200.

Dallas T, Presley SJ. Relative importance of host environment, transmission potential and host phylogeny to the structure of parasite metacommunities. Oikos 2014; 123(7): 866-874. http://dx.doi.org/10.1111/oik.00707.

Digiani MC, Kinsella JM. A new genus and species of Heligmonellidae (Nematoda: Trichostrongylina) parasitic in Delomys dorsalis (Rodentia: Sigmodontinae) from Misiones, Argentina. Folia Parasitol (Praha) 2014 61(5): 473-478. http://dx.doi.org/10.14411/fp.2014.043. PMid:25549502.

Dormann CF, Gruber B, Fründ J. Introducing the bipartite Package: analysing ecological networks. R News 2008; 8(2): 8-11.

Dümmer B, Ristau K, Traunspurger W. Varying patterns on varying scales: a metacommunity analysis of nematodes in European lakes. PLoS One 2016; 11(3): e0151866. http://dx.doi.org/10.1371/journal. pone.0151866. PMid:27008422. 
Gomes DC, Lanfredi RM, Pinto RM, Souza W. Description of Trichuris travassosi $\mathrm{n}$. sp. (Nematoda: Trichurinae) from a Brazilian rodent, by light and scanning electron microscopy. Mem Inst Oswaldo Cruz 1992;87(Suppl 1): 1-10. http://dx.doi.org/10.1590/S0074-02761992000500004. PMid:1343784.

Gressler LT, Krawczak FS, Knoff M, Monteiro SG, Labruna MB, Binder LC, et al. Litomosoides silvai (Nematoda: Onchocercidae) parasitizing Akodon montensis (Rodentia: Cricetidae) in the southern region of Brazil. Rev Bras Parasitol Vet 2017; 26(4): 433-438. http://dx.doi.org/10.1590/ s1984-29612017060. PMid:29069160.

Han BA, Schmidt JP, Bowden SE, Drake JM. Rodent reservoirs of future zoonotic diseases. Proc Natl Acad Sci USA 2015; 112(22): 7039-7044. http://dx.doi.org/10.1073/pnas.1501598112. PMid:26038558.

Higgins CL. Elements of metacommunity structure [online]. Stephenville, Texas: Tarleton State University; 2008 [cited 2018 May 05]. Available from: https://faculty.tarleton.edu/higgins/metacommunity-structure.html

Hugot J-P, Baujard P, Morand S. Biodiversity in helminths and nematodes as a field of study: an overview. Nematology 2001;3(3): 199-208. http:// dx.doi.org/10.1163/156854101750413270.

ICMBio. Parque Nacional da Serra dos Órgãos [online]. Teresópolis: Ministério do Meio Ambiente; 2014 [cited 2014 Out 4]. Available from: http://www.icmbio.gov.br/parnaserradosorgaos

Jiménez-Ruiz FA, Gardner SL. The nematode fauna of long-nosed mice Oxymycterus spp. from the Bolivian Yungas. J Parasitol 2003; 89(2): 299308. http://dx.doi.org/10.1645/0022-3395(2003)089[0299:TNFOLM ]2.0.CO;2. PMid:12760644.

Khalil LF, Jones A, Bray RA. Keys to the cestode parasites of vertebrates. Wallingford: CAB International; 1994.

Leibold MA, Mikkelson GM. Coherence, species turnover, and boundary clumping: elements of meta-community structure. Oikos 2002; 97(2): 237-250. http://dx.doi.org/10.1034/j.1600-0706.2002.970210.x.

Leite RN, Kolokotronis S-O, Almeida FC, Werneck FP, Rogers DS, Weksler M. In the wake of invasion: tracing the historical biogeography of the South American cricetid radiation (Rodentia, Sigmodontinae). PLoS One 2014; 9(6): e100687. http://dx.doi.org/10.1371/journal. pone.0100687. PMid:24963664.

Machado FS, Lima IJ, Lopes APM, Moura AS, Abreu TCK. New occurrences and biological aspects to four species of rodents (Mammalia: Cricetidae) from Brazil. Rev Agrogeoambiental 2016; 8(2): 35-51.

Maldonado A Jr, Gentile R, Fernandes-Moraes CC, D’Andrea PS, Lanfredi RM, Rey L. Helminth communities of Nectomys squamipes naturally infected by the exotic trematode Schistosoma mansoni in southeastern Brazil. J Helminthol 2006; 80(4): 369-375. http://dx.doi.org/10.1017/ JOH2006366. PMid:17125546.

Maldonado A Jr, Pinheiro J, Simôes RO, Lanfredi RM. Canaania obesa (Platyhelminthes: Dicrocoeliidae): redescription and new hosts records. Zoologia 2010; 27(5): 789-794. http://dx.doi.org/10.1590/S198446702010000500015.

Melo GL, Miotto B, Peres B, Cáceres NC. Microhabitat of small mammals at ground and understorey levels in a deciduous, southern Atlantic forest. An Acad Bras Cienc 2013; 85(2): 727-736. http://dx.doi.org/10.1590/ S0001-37652013000200017. PMid:23828340.

Morand S, Poulin R, Rohde K, Hayward C. Aggregation and species coexistence of ectoparasites of marine fishes. Int J Parasitol 1999; 29(5): 663-672. http://dx.doi.org/10.1016/S0020-7519(99)00029-6. PMid:10404260.
Navone GT, Notarnicola J, Nava S, Roble MR, Galliari C, Lareschi M. Arthropods and helminths assemblage in sigmodontine rodents from wetlands of the Río de la Plata, Argentina. Mastozool Neotrop 2009; 16(1): 121-134.

Notarnicola J, Bain O, Navone GT. Two new species of Litomosoides (Nematoda: Filarioidea) in Sigmodontines (Rodentia: Muridae) from Rio de La Plata marshland, Argentina. J Parasitol 2000; 86(6): 1318-1325. http://dx.doi.org/10.1645/0022-3395(2000)086[1318:TNSOLN]2.0 .CO;2. PMid:11191910.

Notarnicola J, Bain O, Navone GT. Litomosoides anguyai n. sp. (Nematoda: Onchocercidae) from Oxymycterus misionalis (Rodentia: Muridae) in the rain forest of Misiones, Argentina. Syst Parasitol 2002; 52(2): 129-135. http://dx.doi.org/10.1023/A:1015632232464. PMid:12075131.

Notarnicola J, Navone GT. A new species of Litomosoides Chandler, 1931 (Nematoda: Filarioidea) from the long-nosed hocicudo Oxymycterus nasutus Waterhouse (Rodentia: Cricetidae) in Uruguay. Syst Parasitol 2009; 73(2): 87-94. http://dx.doi.org/10.1007/s11230-009-9179-5. PMid:19424788.

Paglia AP, Fonseca GAB, Rylands AB, Herrmann G, Aguiar LMS, Chiarello AG, et al. Annotated checklist of brazilian mammals. Arlington: Conservation International; 2012. (Occasional Papers in Conservation Biology; 6).

Panisse G, Robles MR, Digiani MC, Notarnicola J, Galliari C, Navone GT. Description of the helminth communities of sympatric rodents (Muroidea: Cricetidae) from the Atlantic Forest in northeastern Argentina. Zootaxa 2017; 4337(2): 243-262. http://dx.doi.org/10.11646/zootaxa.4337.2.4. PMid:29242441.

Patton JL, Pardiñas UFJ, D'elía G. Mammals of South America - volume 2: rodents. Chicago: The University of Chicago Press; 2015. http://dx.doi. org/10.7208/chicago/9780226169606.001.0001.

Pereira LG, Geise L, Cunha AA, Cerqueira R. Abrawayaomys ruschii Cunha \& Cruz, 1979 (Rodentia, Cricetidae) no Estado do Rio de Janeiro, Brasil. Pap Avulsos Zool 2008; 48(5): 33-40.

Pinto RM, Knoff M, Gomes DC, Noronha D. Nematodes from mammals in Brazil: an updating. Neotrop Helminthol 2011; 5(2): 139-183.

Poulin R. Population abundance and sex ratio in dioecious helminth parasites. Oecologia 1997; 111(3): 375-380. http://dx.doi.org/10.1007/ s004420050248. PMid:28308132.

Poulin R. Evolutionary ecology of parasites. 2nd ed. Princeton: Princeton University Press; 2007.

Poulin R. Network analysis shining light on parasite ecology and diversity. Trends Parasitol 2010; 26(10): 492-498. http://dx.doi.org/10.1016/j. pt.2010.05.008. PMid:20561821.

Presley SJ, Higgins CL, Willig MR. A comprehensive framework for the evaluation of metacommunity structure. Oikos 2010; 119(6): 908-917. http://dx.doi.org/10.1111/j.1600-0706.2010.18544.x.

Püttker T, Meyer-Lucht Y, Sommer S. Effects of fragmentation on parasite burden (nematodes) of generalist and specialist small mammal species in secondary forest fragments of the coastal Atlantic Forest, Brazil. Ecol Res 2008; 23(1): 207-215. http://dx.doi.org/10.1007/s11284-007-0366-z.

Robles MR, Navone GT. New host records and geographic distribution of species of Trichuris (Nematoda: Trichuriidae) in rodents from Argentina with an updated summary of records from América. Mastozool Neotrop 2014; 21(1): 67-78. 
Robles MR. La importancia de los nematodes Syphaciini (SyphaciinaeOxyuridae) como marcadores específicos de sus hospedadores. Mastozool Neotrop 2010; 17(2): 305-315.

Robles MR. New species of Trichuris (Nematoda: Trichuridae) from Akodon montensis Thomas, 1913 of the Paranaense forest in Argentina. $J$ Parasitol 2011; 97(2): 319-327. http://dx.doi.org/10.1645/GE-2434.1. PMid:21506781.

Simões RO, Gentile R, Rademaker V, D’Andrea PS, Herrera H, Freitas $\mathrm{T}$, et al. Variation in the helminth community structure of Thrichomys pachyurus (Rodentia: Echimyidae) in two sub-regions of the Brazilian Pantanal: the effects of land use and seasonality. J Helminthol 2010; 84(3): 266-275. http://dx.doi.org/10.1017/S0022149X09990629. PMid:19849884.

Simóes RO, Luque JL, Gentile R, Rosa MCS, Costa-Neto S, Maldonado A Jr. Biotic and abiotic effects on the intestinal helminth community of the brown rat Rattus norvegicus from Rio de Janeiro, Brazil. J Helminthol 2016; 90(1): 21-27. http://dx.doi.org/10.1017/S0022149X14000704. PMid:25264030.

Simões RO, Souza JGR, Maldonado A Jr, Luque JL. Variation in the helminth community structure of three sympatric sigmodontine rodents from the coastal Atlantic Forest of Rio de Janeiro, Brazil. J Helminthol 2011; 85(2): 171-178. http://dx.doi.org/10.1017/S0022149X10000398. PMid:20701831.

Souza JGR, Digiani MC, Simões RO, Luque JL, Rodrigues-Silva R, Maldonado A Jr. A new heligmonellid species (Nematoda) from Oligoryzomys nigripes (Rodentia: Sigmodontinae) in the Atlantic Forest, Brazil. J Parasitol 2009; 95(3): 734-738. http://dx.doi.org/10.1645/ GE-1836.1. PMid:19642806.

Sutton CA, Durette-Desset MC. Nippostrongylinae (NematodaTrichostrongyloidea) parasites d'Oryzomys flavescens en Argentine et en Uruguay. Rev Suisse Zool 1991; 98(3): 535-553. http://dx.doi.org/10.5962/ bhl.part.82072.
Sutton CA, Lunaschi LI. Contribucion al conocimiento de la fauna parasitologica Argentina XVI. Digeneos en Holochilus brasiliensis vulpinus (brants) y Oryzomys flavescens (waterhouse) de Argentina y Uruguay. Neotropica 1990; 36(95): 13-22.

Thul JE, Forrester DJ, Abercrombie CL. Ecology of parasitic helminths of wood ducks, Aix sponsa, in the Atlantic flyway. Proc Helminthol Soc Wash 1985; 52(2): 297-310.

Travassos L. Revisão da família Trichostrongylidae Leiper 1912. Mem Inst Oswaldo Cruz 1937; 1: 1-512.

Urquhart GM, Armour J, Duncan JL, Dunn AM, Jennings FWW. Parasitologia Veterinária. Rio de Janeiro: Guanabara Koogan; 1998.

Vicente JJ, Rodrigues HO, Gomes DC, Pinto RM. Nematóides do Brasil. Parte V: nematóides de mamíferos. Rev Bras Zool 1997;14(Suppl 1): 1-452. http://dx.doi.org/10.1590/S0101-81751997000500001.

Vidal-Martínez VM, Wunderlich AC. Parasites as bioindicators of environmental degradation in Latin America: a meta-analysis. J Helminthol 2017; 91(2): 165-173. http://dx.doi.org/10.1017/S0022149X16000432. PMid:27346709.

Vilela JF, Mello B, Voloch CM, Schrago CG. Sigmodontine rodents diversified in South America prior to the complete rise of the Panamanian Isthmus. J Zoological Syst Evol Res 2014; 52(3): 249-256. http://dx.doi. org/10.1111/jzs.12057.

Werk DF, Gallas M, Silveira EF, Périco E. New locality records for Guerrerostrongylus zetta (Travassos, 1937) Sutton \& Durette-Desset, 1991 (Nematoda: Heligmonellidae) parasitizing Oligoryzomys nigripes (Olfers, 1818) (Rodentia: Sigmodontinae) from southern Brazil. Check List 2016; 12(2): 1-5. http://dx.doi.org/10.15560/12.2.1861.

Wolinska J, King KC. Environment can alter selection in host-parasite interactions. Trends Parasitol 2009; 25(5): 236-244. http://dx.doi. org/10.1016/j.pt.2009.02.004. PMid:19356982.

Yamaguti S. Systema Helminthum: the nematodes of vertebrates. New York: Interscience Publisher; 1961. 